\title{
In Pursuit of the Employees' Welfare in the Workplace: Issues in Perspectives
}

\author{
Olufunmilayo F. Odeku
}

\author{
Kola O. Odeku \\ Faculty of management and Law, School of Law University of Limpopo, South Africa
}

\author{
Doi:10.5901/mjss.2014.v5n15p652
}

\section{Abstract}

Employees are important to the progress of any organisation so, they should be kept happy and provided for with sustainable wages, welfare packages and other incentives which are not always given. It is therefore not unusual to see labour unrest as a result of complains of poor welfare provisions and services to the workers. Employees are of the perception that although capital is provided by the employers, they are the main resource used to bring about output and production which eventually bring back the investment and huge dividends to the employers. This paper looks at how existing labour laws in Nigeria are serving as protective mechanisms toward the welfare of the employees in the workplace.

Keywords: Incentives, workers, benefits, workplace, productivity, socio economic goods and services.

\section{Introduction}

Workers are essential to the means of production (Drucker, 2010); they deserve to be treated with respect and given proper welfare packages and incentives (Noguera, 2005). These will improve their sense of worth, boost their selfesteem, financial status and act as, a sort of motivation to drive them to have more passion for their job, increasing their productivity Thorsen, 2006). This is what is expected to be pursued by employers who look beyond instant profit making as opposed to enduring sustainable business earning of profits in perpetuity (Deeprose, 2006). Lack or inadequate welfare packages and other incentives leads to poor worker's motivation which greatly affect their outcomes and productivity hence, there is need for employers to give staff welfare package and other incentives for the benefits of the employees, employers and the organisation (Okereke and Daniel 2010).

There has been a lot of concerted efforts at national and international levels to set standards with minimal government interference and free market forces that would serve as framework to guide labour relations between employees and employers and thus confer on workers certain rights once there is an established contract of employment (Oginni and Adesanya, 2013) With regard to how workers welfare is advanced in Nigeria, the most important instrument which provide ample protection and entitlement to the workers is the Constitution which prescribes for rights, obligations, duties and responsibilities of the corporate and non-corporate entities (Okene, 2009). It is pertinent to point out that Nigeria operates a federal system of government, where powers are constitutionally shared between the central government and the components administrative units (Suberu, 2001). Certain powers are devolved to the components political units like the state and the local government. Matters relating to labour control are vested exclusively in the central government or national government (Aiyede, 2004). Thus, section 4(ii) of the constitution of the Federal Republic of Nigeria provides as follows: "the National Assembly shall have power to make laws for the peace, order and good government of the federation on any part thereof with respect to any matter included in the exclusive legislative list set out in part one of the second schedule to this constitution."

There is an extensive list of 68 subject matters covered by the aforesaid exclusive legislative list. The $34^{\text {th }}$ item on that list is specified as follows: "labour, including trade unions, industrial relations; conditions, safety and welfare of labour industrial disputes; prescribes a national minimum wage for the federation on any part thereof, and industrial arbitrations." Thus, all labour statues apply throughout the country unless a particular labour statute provides otherwise. Workers all over the world deserve recognition, good salaries, wages and great improvements in the terms and conditions of work (Narasimhan et al. 2004), thus workers have formed associations for realizing their main objectives dignify and sustainable welfare packages in the workplace (Aldrich, 2008) and to realize improvements in their working conditions (Schneider and Bowen, 2010). Both the Nigerian Labour Laws and International Laws recognize the rights of workers to bargain collectively for the protection of the legitimate interest of workers which can be achieved (Howse, 1999). These 
laws are however not taken seriously by employers as they are not held responsible most times for labour offences and due to high unemployment rates in the country, employees often suffer in silence (Danesi, 2010). The reason for not taking the laws seriously is as a result of lack of enforcement on the side of the institutions that have been put in place to monitor and ensure compliance. It is against the backdrop of this gap in oversight that Adewunmi and Adenugba (2010) point out that employers in Nigeria are taking advantage of the weak institutional and regulatory framework to the detriment of their employees (Okene, 2006). As long as this situation persists, workers' right to collective bargaining especially for essential welfare package would continue to be abridged (Adenugba, 2010). The truth is that, employers do not want to share the control of employment relations with their employees (Whitener, 1998). That is why they are coming up with a new managerial ideologies and philosophies to justify their position (Marcuse, 2013). According to Adenugba (2010), "an official of the Nigerian Employers Consultative Association (NECA) stated that most employers adopt the modern model of industrial relations which discourages the formation of workers' union and the use of collective bargaining to fix terms and conditions of work." This is the new trend in industrial relations is employee relations, which emphasizes individualism instead of collectivism, hence, the use of Joint Consultative Council instead of collective bargaining to settle industrial conflict (Ikeanyibe, 2012). In employee relations, since there is no union and union leaders, opinion leaders are invited to participate in Joint Consultative Council. This new trend in industrial relations is nothing other than the situation that has been promoted by the ascendancy of neo-liberalism as the framework of global trends (Terry, 2003).

\section{Historical Background of the Nigerian Labour Law}

An examination of the historical overview of Labour Laws in Nigeria is very critical. This is because the understanding of the history of the trade unionism in Nigeria is essential for the proper appreciation of the events that led to the enactment of these labour laws (Balkaran, 2011). Wage earning employment was not known to the indigenous Nigerian communities until the advent of the colonialist. What existed then was communal labour and trade by barter (Joseph, 2014). Thus, under the communal labour system, members were paid back in services rather than in money (Berry, 1993). The advent of the colonialist led to the development of wage earning and employment (Hopkins, 1996). With the development of wage earning employment and a monetized economy, Labour Laws began to evolve to regulate Master-ServantRelationship. Most of these legislators came up with 'alien' ideas which are different from the colonial masters-Britons (Albert, 2014). However, after the attainment of political independence in 1960, most Nigerian Laws including Labour Laws are essentially reproduction of the English Laws (Mwalimu, 2005).

\section{Literature Review}

The issues surrounding welfare and good quality of life for workers who are used in productive activities but denied basic social economics incentives to improve their quality of life are becoming more challenging and controversial these days (Bowen, 2013). These issues often result into conflicts leading to union members declaring dispute which may culminate to strike actions or lock-outs (Stiglitz et al. 2009). Although there are ample laws that have been put in place to compel employers to provide welfare packages to the employees, implementation and enforcement are the major impediments to the realisation of the provisions of the laws (Weiler, 2009). Most times, employees renege in their promises to provide welfare knowing very well that employees are vulnerable and would rather keep silence in the face of blatant violation of their rights to welfare than face the reprisal (Little, 2001).

Lack of or inadequate welfare package to the employees limits the social and organizational conditions of workers and impact on their productivity (Elson and Pearson, 1981). It could impact also on the team spirit which according to Vallas (2003) limits " the firm's ability to provide an overarching normative or moral framework within which workplace change might unfold, leaving team systems vulnerable to anomic tendencies, to status distinctions among hourly employees, and to other sources of instability"

A full time employee is supposed to be entitled to a living wage, good working conditions, leave allowance benefits and vacations. The extent to which these are actually made available and beneficial to the employees in the workplace however leaves much to be desired (Becker and Huselid, 2006). Existing labour literature has shown that eemployees tend to put in their best, work effectively and efficiently if the work environment is conducive and the management and corporate executives demonstrate the flexibility that they often demand of their employees (Fernández, 2003).

In order to promote sustainable output in the workplace, apart from what the law prescribed to be given as welfare to employees, employers should also be more innovative when it comes to dealing with welfare (Nativel, 2006). Undoubtedly, this will serve as incentive and motivate workers to go the extra mile by working harder. The importance of 
upgrading skills is also vital as part of welfare in the workplace. Against this backdrop, Vallas (2003:34) points out that "the governments of OECD member countries have begun to acknowledge the importance of upgrading the human capital of those workers trapped in low-skilled, low-paid and often insecure jobs. The emerging literature on workforce development and lifelong learning confirms that this agenda has become a central labour market policy challenge for the 21s." Quoting the report of the EU Employment Taskforce 2003:47, Vellas (2003:34) went further to assert that "the report of the EU Employment Taskforce argued that it is imperative to prevent an obsolescence of skills in order to maintain people at work longer, and this means that training has to be targeted also at older workers and low-skilled workers." The overarching importance of incentives in human capital is therefore now a "paradigm shift from "welfare-to-work" to "welfare-in-work certainly suggests that some governments - especially in English-speaking countries - are increasingly willing to redraw the boundaries of their labour market intervention."

Okereke et al. (2010) examined "staff welfare and organization's productivity, using Patani Local Government Council in Delta State, Nigeria as a reference... Data revealed general awareness about staff welfare among the employees and ability to identify the elements of welfare. There was absence of staff welfare in the council. The working environment was poor, in terms of office accommodation and furniture, paucity of working materials, scarcely available monetary incentives and unreliable health and safety facilities, which altogether reduce morale (job satisfaction) and efficiency in job performance."

One of the notable recommendations from the work of Okereke and Daniel (2010) is that "pragmatic efforts should be made to enhance employee's job capabilities through training; to improve working conditions of the employees and their general welfare in order to elicit job satisfaction and motivation for increased productivity."

The study of Chirda et al. (2009) showed that workers will be more motivated to do their work if salaries are competitive and market related, if the management supports staff welfare and encourage "managerial support for staff career development, availability of tools and consumables in the workplace and progress towards personal professional goals appears play a role in worker motivation." With regard to the issue of realisation of the incentives and welfare suggested by Chirda et al. (2009), there is need to be administrative will on the part of the employers to implement and also political will on the part of the regulator to compel and enforce compliance and performance.

Akintayo (2012:251) investigated "the relationship among working environment, workers' morale and perceived productivity in industrial organizations in Nigeria. This was for the purpose of ascertaining the influence of working environment, workers' morale and perceived productivity among industrial workers in Nigeria." The study found that "a significant relationship exist among working environment, workers' morale and perceived productivity....working environment is significantly related to workers morale. Besides, working environment has significantly correlated with perceived workers " productivity."

The following recommendation was made "the working environment which embraces organizational support programmes, training and development, substantive welfare package and conducive socio-political environment should be provided for workers. This will definitely facilitate improved workers' morale and increased productivity at workplace" (Akintayo, 2012).

Studies have also shown that the issues of welfare and incentives in the workplace are now becoming global phenomenon and there is increase in welfare-related activism to ensure that workers welfare is taking more seriously by the employers. (Daly, 2002). In spite of this, there have long been conflicting expectations of the nature of companies' responsibilities to the employees and the society (Eichhorst and Hemerijck, 2008). Employers are therefore enjoined to do this in order to motivate their employees (Moir, 2001).

In the employment sphere, according to Griffin (1986) "Well-being," welfare, utility," and quality of life are all closely related concepts. They are also at the centre of morality, politics, law, and economics (Griffin, 1986).

The study conducted by Morgen (2001) revealed that "the neoliberal agenda of downsizing the state and minimizing its role in regulating the market has shaped welfare policy and the work of welfare provision." The study further revealed "self-sufficiency, the professed goal of welfare to-work programs, is a complex concept, saturated with ideological meaning. Examination of the work of welfare provision provides an opportunity to analyze how workers give meaning to self-sufficiency and construct their work as positive for the families they serve" (Morgen, 2001).

Nadler and Lawler (1983) indicated that "the real thrust of quality-of-work-life programs-improving organizational life and behavior and the fundamental health of the organization-should result in a higher level of organizational performance and a better work environment."

Hollar (2003) has warned that "assessing the human impact of policy change requires more than evaluating economic outcomes; it requires knowing the resources of beneficiaries of social services and their conditions of life from various perspectives. Thus, we must strive for greater understanding about the sociocultural aspects of people's lives that create the whole person-aspects such as health, family and friendship networks, housing situations, public and private 
support service and program use, conditions of work, and so forth. This is how we come to understand one's quality of life. The present research creates a conceptual model of quality of life and illustrates the model using data from a followup study of former welfare recipients in a county in northern Virginia. Evaluation activities that are premised on a qualityof-life model will help policy actors understand the impact of policies and how public institutions can be managed strategically within their very complex contexts, especially in an era of welfare reform."

Mirvis and Lawler (1984) study "describes the development and issuance of an independent report on the quality of work life in a Corporation. The theory underlying the report, criteria, definitions, measurement procedures, the properties of the measures, and report itself are presented. A survey indicating a favourable reception to the data by stockholders, financial analysts, and employees is analysed. Recommendations for increased collaboration between accountants and behavioural scientists in the measurement and assessment of the quality of work life are presented in an effort to stimulate further research in the development of standardized measures and in the preparation of independent reports on the quality of work life in organizations."

Lau and May (1986) study "develops and tests hypotheses to examine empirically how the perceived image of a company's quality of work life will affect its market and financial performances. Growth and profitability of two groups of publicly held companies were compared based on sales growth, asset growth, return on equity, and return on assets. The first group consisted of fifty-eight companies identified as the best companies to work for in the United States; the second group consisted of eighty-eight of Standard and Poor's top one hundred companies. Statistical evidence found in this study supports a paradigm that aligns the interests of the investor, manager, and employee stakeholders into a win-win situation. Findings from this empirical study suggest that companies with high quality of work life can also enjoy exceptional growth and profitability."

Brush (2000) study revealed that "battering and its consequences may thwart welfare recipients' transition from welfare to work, complicating welfare reform. This research examined battering and traumatic stress in the lives of 122 enrollees in a short-term job readiness program. Nearly half reported violence or serious injury in their current or most recent intimate relationship. One third reported traumatic stress symptoms. The data help assess the relative importance of potential barriers to welfare-to-work transition, including character and human capital deficits, gendered caring responsibilities, and battering and its consequences. Feminist accounts that include battering explain program participation outcomes better than accounts that focus only on deficits."

\subsection{Sources of Nigerian labour laws}

The Nigerian Labour originated from various sources which are:

The Received English Law: The English Law is a major source of Nigerian Law and as stated earlier in this research work, this is a reflection of the colonial relationship Nigeria had with Britain (Ibhawoh, 2002). Most of the received English Labour Laws have been domesticated in Nigeria by Acts of the National Assembly (Mbah and Ikemefuna, 2011).

The received English Law is made up of the following:

a. The Common Law: The rules of Common Law still largely regulate the contract of employment in Nigeria.

b. Doctrines of Equity: The role of equity in Labour relations is confined to the provisions of equitable remedies such as a declaration order of injunction and specific performance.

c. Statutes in force in England on or before January 1, 1900.

Nigerian Labour Legislations: These are various Labour Legislations made by the various Legislative Houses in Nigeria. It comprises of Acts of Parliament, Laws of the States of Houses of Assembly, Decrees and Edicts (Under Military Regimes), Bye Laws of the Local Government Authorities and Subsidiary Legislations. Thus, Labour Legislations in Nigeria include the Factory Decree (1987), Workmen Compensation Decree (1987), Trade Disputes Act (1976), Labour Act (1974) and so on (Omenka, 2008).

Case Law: Judicial decisions on different facets of the subject form an important source of Labour Laws in Nigeria and where they exist; such decisions remain an authoritative source of interpreting principles of statutory provisions (Temitope, 2010).

International Laws: This includes basically the Customary International Laws and International Treaties (convention) relating to Labour and employment. There are several International Labour Organisations (ILO) Conventions relating to Labour and Employment and so on. The ILO Declaration Fundamental Principles and Rights at Work (2000), ILO Conventions 1987 on Freedom of Association and Protection of the Rights of the Employees was organize in 1948 and 1949 respectively. Whenever Nigeria is a signatory to any of such Treaty, the provisions of such a Treaty becomes part of Nigerian Law and can be invoked and enforced by the Nigerian Courts provided the treat/convention in question 
has been enacted into Law by an Act of the National Assembly (Enabulele, 2009).

The Nigerian Constitution: The 1999 constitution, like its predecessors has several provisions relating to Labour and Employment. See for example, Section 17 (3), 34, 40, 41 and 42 of the constitution of the Federal Republic of Nigeria (1999). Although, section 17 of the constitution is generally non-justiceable, i.e (cannot be enforced in a Law court), some of the provisions of section 17 (3) have been embodied in existing legislations such as the Labour Act (1994), Workmen Compensation Decree (1987), Factories Decrees (1987) (Inegbedion and Omoregie, 2006).

Subsidiary Sources: The following are the subsidiary sources of Labour Law in Nigeria:

Collective agreement: Collective Agreements serves as a source of Labour Law by providing rules and terms which regulates contract of employment.

Workplace notices and documents: Employers may issue to their employees Rule Books, Handbooks, Staff Manuals and sometimes post notice also known as internal circulars in the work place on specific matters (Fashoyin, 1990). The provisions of these Notices and Documents may constitute terms of the employment if they can be incorporated into contract of employment (Adediji, 2012).

Customs and practices: Custom and practice or trade usage may constitute a source from which terms regulating the individual Contract of Employment may be derived (George, 2010). However, for custom and practices to become incorporated into Contract of Employment, they must be reasonable, certain and noxious (Dowling, 2001).

\section{What Constitute Employee's Welfare?}

Worker's right is a very broad issue; however, it can be brought down to the protection and respects of human life in the work place and the right to work itself (Seidman, 2007). Some components of workers' rights are the right to job safety, collective bargaining and equal pay for equal work and employee's welfare (Laura et al. 1996).

However, the focus of this work is on the employee's welfare, such as Medicals and Medical Compensation, Annual and Maternity Leave, Compassionate and Sick Leave. Staff welfare is a major issue in industrial relations because welfare programmes and services enhance profitability but with bottom-line employees and high level of unemployment, employers have more room to dodge welfare services (Solow, 2009).

Employee's welfare is also referred to as better work opportunities for employees, which also relates to taking care of the well-being of workers by Employers of labour, Trade Unions, Government and Non-Governmental Agencies (Goldman, 1999). International Labour Organization (ILO) at its Asian Regional Conference, defined employee's welfare as a term which is understood to include accessibility to services such as facilities and amenities as may be established in or in the vicinity of undertakings to enable the persons employed in organisations to perform their work in a healthy, congenial environments conducive to good health and high morale (Murugan, 2013).

Employee's welfare has two aspects, negative and positive (Osterman, 2000). On the negative side, the employee's welfare is concerned with counteracting the beneficial effects of the large scale industrial system of production ( Henkel and von Hippel, 2005). On the positive side, it deals with the provision of opportunities for the worker and his/her family for a good life as understood in its most comprehensive sense (Gaikwad, 2013).

A further argument in favour of employee's welfare is that it gives a reputation that shows care and concern on the part of the employee and helps improve the local image of the Company as a good employer (Cohen and Prusak, 2001). Good reputation assists the organisation's recruitment processes and productivity in the long run. Welfare may not directly increase productivity,(Armstrong, 2003) but it may add to the general feelings of satisfaction with the company, improves the self-worth of the employee and cut down on employee turnover (GGrigore and Stancu 2011).

\subsection{Institutional capacity and protection of employee's welfare}

Apart from legislation, the formalized employment relationship is regulated and mediated by a number of structures and institutions which are located within the frame work of the Labour Administrative System (Peck, 1996). Article 1 of the ILO Convention 150 defines labour administration as public administration activities in the field of national labour policy (incorporating labour, employment and vocational training) vehicle while the system of labour administration covers all public administrative bodies responsible for and or engaged in labour administration whether they are ministerial departments or public agencies, including parastatal and regional or local agencies or any form of decentralized administration and any institutional framework for the coordination of activities of such bodies and for consultation with and participation. This is the institutional framework for ensuring compliance with laws and standards as well as protecting employee's welfare. It is the essential duty of Labour administration to enforce labour legislation and to offer solution to the various complex problems that arise in the world of work (Daza, 2005). 
Some of the components of labour administrative system that are of interest to us here include, the Federal Ministry of Labour and Productivity, particularly the Department of Trade Union Services and Industrial Relations Department including the Industrial Arbitration Panel and Inspectorate, the National Industrial Court and the National Labour Advisory Council (Tajudeen and Kehinde, 2007). In spite of the political allegiance of government to the ruling class whose members constitute the bulk of the employers of labour, it is still expected to protect the interest of all irrespective of class affiliation or social standing (Olayode, 2011). As such within the employment relationship, government through relevant agencies are expected to ensure that parties involved get a fair deal ( Fairclough, 2000).

Furthermore, Adewumi and Adenugba (2010:19) vehemently asserted that "there is no doubt that the Ministry of Labour lacks enough capacity to carry out its mandate. There is shortage of personnel to carry out inspection service nationwide. This development has in turn, reduced the capacity of the system to deliver even when there is the will. The Ministry is short staffed, even in very critical areas. For example, as at 2010, the Factory Inspectorate was made up of only 47 staff)." They also pointed out that "by the Ministry's own calculation, a minimum of 250 inspectors are required for effective inspection. In fact, it is claimed by trade union officials (as confirmed by official records of the Federal Ministry of Labour) that there is only one Factory Inspector in of the whole of the North-East. Needless to say those facilities such as vehicles to facilitate inspection visits to the work establishments are hard to come by. Again, By the Ministry's admission and as at 2010 , there was not a single vehicle for inspection, yet 63 vehicles are needed."

\subsection{Trade unions and protections of employee's welfare}

If the Agencies of the Nigerian States are not doing enough, what has been the response of the trade unions? Since the unions interact with the labour administrative bodies what have they been able to secure, the welfare of their members? The simple truth is that the unions in have not been able to do much (Gilroy, 2013). A combination of factors, internal and external including conspirator's indifferences of a consuming public that is quick to condemn any collective action of workers because of possible inconveniencies without being commensurately bothered about the plight of the employees. For instance, the industrial action (strike) of organized labour of June 2007 against some governmental policies was effectively organised and implemented but less than one week of the industrial action, there was enough public out-cry against the action with appeals to labour to consider the plight of the people and call of the strike.

Before proceeding further, one pertinent question to ask is whether the unions are in a position to make a difference and the answer is Yes, the unions can.

The unions sometimes are in a position to make a difference through collective platform offered by the unions' presents a good avenue for workers to press for, and demand for other rights (Kabeer, 2004). This is not to say that unions are not without their own problems which should be addressed to ensure a better deal (Obama, 2008). These problems includes weak organization, inadequate resources; human and materials, lack of inclusiveness in organization and representation of union organs, membership apathy and lack of commitment on the part of union officials (Adewumi, and Adenugba, 2010). Of course, the unions are operating in a very hostile environment dominated by powerful people trans-national corporations, whose examples indigenous employers follow (Adewumi, and Adenugba, 2010). Citing a critical sector in the Nigeria, Adewumi, and Adenugba (2010), pointed out that "in the oil and gas sector, employers in the Nigeria's oil and gas sector have not been particularly well disposed towards unionism for a long time." Onyishi et al. (2012) also, vehemently subscribed to this view. Adewumi, and Adenugba (2010) asserted that "this is reflected in their refusal to recognize and negotiate with the union executives om victimization and dismissal of active workers, the use of threats, bribery and the infiltration of unions," which in the words of Ihonvbere (1994) are "definitely aimed at controlling workers." This trend is entrenched and seems to continue in perpetuity without any sign of it being nipped in the bud. This is contrary to the position of the ILO that states that "there should be no barriers to the free association of employers and workers for the purpose of regulating their employment relationship" (ILO 1997). Even where unions are recognized, there is a reluctance to enter into negotiations with them and when agreements are reached and in particular regarding the issues of workers welfare and well-beings (Coulby, 2009). Employers have lackadaisical attitudes toward workers and unions when it comes to fulfilling what had been agreed on (Chandratilleke, 2003). This is why there are always tensions and conflicts in the workplace.

\section{Conclusion}

Promoting an atmosphere of positive incentive and welfare packages will enhance workers' productivity and impact hugely on the return on investment made by the employers and stakeholders. Utilising short cuts and pretence by employers to deny and frustrate the employees from receiving welfare benefits will create tensions in the workplace. 
Employer engaging in this disingenuous activity will lose at the end of the day should the workers exercise their right to strike. Benefits to the workers serve as motivational factor to be more productive. While this is good for the workers, it is equally beneficial to the employers especially if there is increase in production and sales that result into huge profit. In this regard, it becomes a win-win-situation to both parties.

\section{Recommendations}

Employers are enjoined to, at all times, take innovative proactive approach to the issue of staff welfare. Even if they are prescribed in law, the employer can exceed what the law prescribed especially if the workers are doing their bits and growing the business through their massive hard work and productivity.

The employees should not be outrageous and unnecessarily difficult in their approach towards negotiation for improved welfare in the workplace. Both parties have stakes in the business hence, they should sit down and work out an acceptable modality that will be beneficial to both.

\section{References}

Adediji BO 2012. Challenging Issues and Accountability in Nigeria's Public Administration. From . From http://www.econstor.eu/handle 110419/35827. (Retrieved on July 12, 2013).

Adewumi F, Adenugba 2010. A The State of Workers' Rights in Nigeria: An Examination of the banking, oil and gas and telecommunications sectors. from http://www.fes-nigeria.org/common/pdf/the $\% 20$ state $\% 20$ of $\% 20$ worker's $\% 20$ rights $\% 20$ in\%20nigeria.pdf. (Retrieved on March 6, 2014).

Aiyede E R 2004. United we stand: labour unions and human rights NGOs in the democratisation process in Nigeria. Development in Practice, 14(1-2): 224-233.

Akintayo D 2012. Working environment, workers' morale and perceived productivity in industrial organizations in Nigeria. Education Research Journal, 2(3): 87-93.

Albert PJ, Werhane P, Rolph T 2014. Global Poverty Alleviation: A Case Book. The International Society of Business, Economics, and Ethics Book Series, 3(14):13-111.

Aldrich $\mathrm{H}$ 2008. Organizations and environments. California, USA:Stanford University Press.

Armstrong M 2003. A handbook of human resource management practice. London, UK: Kogan Page Ltd.

Balkaran S 2011.The impact of trade unions on public service reform in Nigeria and South Africa: a comparative study. From http://uzspace.uzulu.ac.za/handle/10530/1091. (Retrieved on November 16, 2013).

Becker BE, Huselid MA 2006. Strategic human resources management: where do we go from here? Journal of Management, 32(6):898925.

Berry S 1993. No condition is permanent: The social dynamics of agrarian change in sub-Saharan Africa. Wisconsin, USA:The University of Wisconsin Press.

Bowen HR 2013. Social responsibilities of the businessman. lowa, USA:University of lowa Press.

Brush L 2000. Battering, Traumatic Stress, and Welfare-to-Work Transition. Violence Against Women, 6(10): 1039-1065.

Chandratilleke KL 2003. Social Dialogue in Action: Best practices in social dialogue. From http://english.mol.gov.tw/site/business /414ea820/4213f363/4213f3b0/files/Best\%20Practice\%20in\%20Social\%20Dialogue.pdf\#page=163. (Retrieved on April 16, 2013).

Chirdan OO, Akosu JT, Ejembi CL, Bassi AP 2009. Perceptions of working conditions amongst health workers in state-owned facilities in North Eastern Nigeria. Annals of African Medicine, 8(4): 243-249.

Cohen D, Prusak L 2001. In good company: How social capital makes organizations work. From http://books.google .co.za/books?hl=en\&lr=\&id=jse3a_l4tfqc\&oi=fnd\&pg=pr9\&dq= ots=y95q5nw0w1\&sig=9ijwzuucg9pywujag9peyw_oqfq\#v=onepage\&q\&f=false. (Retrieved on February 19, 2013).

Coulby H 2009. A Guide to Multistakeholder Work. From http://www.waterdialogues.org/downloads/new/Guide-to-Multistakeholder.pdf. (Retrieved on May 22, 2013).

Daly M 2002. Care as a good for social policy. Journal of Social Policy, 2002. Journal of Social Policy. Journal of Social Policy, 31(2): 251-270.

Danesi, RA 2010. Casualisation and International Labour Standards: The Role of Trade Unions in Nigeria, US-China Law Review, 7:111.

Daza JL 2005. Informal economy, undeclared work and labour administration. Available

http://www1.chr.up.ac.za/chr_old/indigenous/documents/Nigeria/Report/Informal\%20Economy,\%20Undeclared\%20Work\%20and\%20La bour\%20Administration.pdf. (Retrieved on April 4, 2013).

Deeprose D 2006. How to Recognize and Reward Employees: 150 Ways to Inspire Peak Performance. New York, USA: Amacom Books.

Dowling DC 2001. The Practice of International Labor \& Employment Law: Escort Your Labor/Employment Clients into the Global Millennium. The Labor Lawyer, 17(1): 1-23. 
Drucker PF 2010. Knowledge-worker productivity: The biggest challenge. New York, USA: Routledge.

Eichhorst W, Hemerijck A 2008. Welfare and employment: A European dilemma? From http://www.econstor.eu/handle/10419/35827. (Retrieved on December 14, 2013).

Elson D, Pearson R 1981. Nimble fingers make cheap workers': An analysis of women's employment in third world export manufacturing. Feminist Review, 7(6): 87-107.

Enabulele AO 2009. Implementation of Treaties in Nigeria and the Status Question: Whither Nigerian Courts. African Journal of International \& Comparative Law, 17:326:334.

Fairclough N 2000. Discourse, social theory, and social research: The discourse of welfare reform. Journal of Sociolinguistics, 4(2): 163195.

Fashoyin T 1990. Labour Relations and Human Resource Management in a Non-Union Nigerian Company. International Journal of Comparative Labour Law and Industrial Relations, 6(1): 36-54.

Fernández E, Junquera B, Ordiz M 2003. Organizational culture and human resources in the environmental issue: a review of the literature. The International Journal of Human Resource Management. 14(4): 634-656.

Gaikwad HV 2013. A study of labour welfare with special reference to bombay rayon fashions limited, islampur, maharashtra. From http://web.a.ebscohost.com/ehost/search/advanced?sid=e38046f0-648d-4736-a18f-be62c397be1d\%40sessionmgr4001\&vid=1 \&hid=4214. (Retrieved on July 7, 2014).

George OJ 2010. Impact of Culture on Employment Relations Practice in Former British Colonies: A Comparative Case Study of Cadbury (Nigeria) Plc and Cadbury Worldwide. From http://repository.unilag.edu.ng:8080/xmlui/handle/123456789/646. (Retrieved on August 21, 2013).

Gilroy P 2013. There ain't no black in the Union Jack. New York, USA: Routledge.

Goldman AL 1999. Potential refinements of employment relations law in the 21st century. Employee Rights and Employment Policy Journal, 3:269-282.

Griffin J 1986. Well-being: Its meaning, measurement, and moral importance. From http://philpapers.org/rec/griwim. (Retrieved on May 9, 2013).

Grigore GE, Stancu A 2011. The role of corporate social responsibility in building employer's brand. From http://web.a.ebscohost.com/ehost/search/advanced?sid=0c77f49f-6439-4075-ba9c-e8e4b7e9c763\%40sessionmgr4002\&vid=1 \&hid=4214. (Retrieved on August 16 2013).

Henkel J, von Hippel E 2005. Welfare Implications of User Innovation. From http:/link.springer.com/chapter/10.1007/0-387-25022-0_5\#. (Retrieved on December 15, 2013).

Hollar D 2003. A Holistic Theoretical Model for Examining Welfare Reform: Quality of Life. Public Administration Review, 63(1): 90-104. Hopkins A G1996. The Lagos Strike of 1897: An Exploration in Nigerian Labour History. Past \& Present. 35: 133-155.

Howse R 1999. World Trade Organization and the Protection of Workers' Rights. Journal of Small \& Emerging Business Law, 3:131-142. Ibhawoh B 2002. Stronger than the maxim gun law, Human rights and British colonial hegemony in Nigeria. Africa, 72(1): 55-83.

Ikeanyibe MO 2012. Emerging trends in labour-managment relations: implications for industrial harmony in the Nigerian public sector, from http://njpalg.org/journals/voltwoxvd/articlefour.pdf. (Retrieved on August 25, 2013).

Inegbedion NA, Omoregie E 2006. Federalism in Nigeria: a re-appraisal. Journal of Commonwealth Law and Legal Education, 4(1): 6983.

Joseph RA- 2014. Democracy and prebendal politics in Nigeria. Cambridge, UK:Cambridge University Press.

Kabeer N 2004. Globalization, labor standards, and women's rights: dilemmas of collective (in)action in an interdependent world. Feminist Economics, 10(1): pages 3-35.

Lau R S M, May BE 1998. A win-win paradigm for quality of work life and business performance. Human Resource Development Quarterly, 9(3): 211-226.

Laura H, Powell C, Volpp, L 1996. (Dis)Assembling Rights of Women Workers Along the Global Assembly Line: Human Rights and the Garment Industry. Harvard Civil Rights Civil Liberty Review, 31: 383-395.

Little M 2001. A litmus test for democracy: The impact of Ontario welfare changes on single mothers. From https://www.mediatropes .com /index.php/spe/article/view/6702/3701. (Retrieved on January 6, 2013).

Marcuse H 2013. One-dimensional man: Studies in the ideology of advanced industrial society. New York, USA:Routledge.

Mbah SE, Ikemefuna CO 2011. Core Conventions of the International Labour Organisation (ILO): Implications for Nigerian Labour Laws. From http://www.sciedu.ca/journal/index.php/ijba/article/view/234. (Retrieved on July 19, 2013).

Mirvis PH, Lawler EE 1984. Accounting for the quality of work life. Journal of Organizational Behavior, 5(3): 197-212.

Moir L 2001. What do we mean by corporate social responsibility? Corporate Governance, 1(2):16 - 22.

Morgen S 2001. The Agency of Welfare Workers: Negotiating Devolution, Privatization, and the Meaning of Self-Sufficiency. American Anthropologist, 103(3): 747-761.

Murugan S 2013. labour welfare \& labour legislation From http://books.google.co.za/books?hl= en\&lr=\&id=se5cagaaqbaj\&oi=fnd\&pg $=$ pa1\&dq $=$. (Retrieved on August 17, 2013).

Mwalimu C 2005. The Nigerian Legal System: Public Law. New York, USA:Peter Lang Publishing, Incorporation.

Nadler DA, Lawler EE 1983. Quality of work life: perspectives and directions. Organizational Dynamics, 11(3): 20-30.

Narasimhan V, Brown H, Pablos-Mendez A, Adams O, Dussault G, Elzinga G, Nordstrom A, Habte D, Jacobs M, Solimano G, Sewankambo N, Wibulpolprasert S, Evans T, Chen L 2004. Responding to the global human resources crisis, The Lancet, 363(9419):1469-1472. 
Nativel C 2006. From welfare-to-work to welfare-in-work: Concepts and policies. From http://www.paca-online.org/cop/docs loecd_local_economic_and_employment_development_skills_upgrading.pdf\#page=35. (Retrieved on December 16, 2013).

Noguera JA 2005. Citizens or Workers - Basic Income vs. Welfare-to-Work Policies. Rutgers Journal Law \& Urban Policy, 2:103-114.

Obama B 2008. A more perfect union. The Black Scholar, 38(1): 17-23.

Oginni B Y and Adesanya A S 2013. The Workers' Rights In Nigeria: Myth Or Reality?, International Journal of Business and Management Invention, 2(1): $2319-8028$.

Okene OVC 2006. Curbing State Interference in Workers' Freedom of Association in Nigeria"' The International Journal of Not-for-Profit Law , 8(4): 86-96.

Okene OVC 2009. Derogations and restrictions on the right to strike under international law: the case of Nigeria. The International Journal of Human Rights, 13(4): 552-580.

Okereke $\mathrm{Cl}$ and Daniel A 2010. Staff welfare and productivity in Patani local government council, Delta State Nigeria. Journal of Economics and International Finance, 2(12): 313-320.

Olayode 2011. Ethno-nationalist movements and political mobilisation in Africa: The Nigeria experience (1990-2003). From http://stichproben.univie.ac.at/fileadmin/user_upload/p_stichproben/Artikel/Nummer20/20_Olayode.pdf. (Retrieved on March 23, 2014).

Omenka Jl 2008. Legislative Oversight and Socio-Economic Development in Benue State. From http://elawnigeria.com larticles/Legislative\%200versight\%20And\%20SocioEconomic\%20.pdf. (Retrieved on May 22, 2013).

Onyishi AO, Eme OI, Emeh IEJ 2012. The Domestic and International Implications of Fuel Subsidy Removal Crisis in Nigeria. Kuwait Chapter of Arabian Journal of Business and Management Review, 1(6):57-80.

Osterman P 2000. Work Reorganization in an Era of Restructuring: Trends in Diffusion and Effects on Employee Welfare. Industrial and Labor Relations Review. 53(2): 179-196.

Peck J 1996. Work-place: The social regulation of labor markets. Guilford Press, New York, USA.

Schneider B, Bowen DE 2010. Winning the Service Game. From http://ink.springer.com/chapter/10.1007/978-1-4419-1628-0_4\#. (Retrieved on August 5, 2013).

Seidman G 2007. Beyond the boycott: Labor rights, human rights, and transnational activism. New York, USA:Russell Sage Foundation,

Solow RM 2009. Work and welfare. New Jersey, USA: Princeton University Press.

Stiglitz J, Sen A, Fitoussi JP 2009. The measurement of economic performance and social progress revisited. From http://www.ofce.sciences-po.fr/pdf/dtravail/WP2009-33.pdf. (Retrieved on November 8, 2013).

Suberu RT 2001 .Federalism and ethnic conflict in Nigeria, From http://www.citeulike.org/group/15968/article/10772638. (Retrieved on June 14, 2013).

Tajudeen AA, Kehinde OK 2007. Government Public Policies and the Dynamics of Employment Relations in Developing Countries: The Experience of Nigeria. Pakistan Journal of Social Sciences, 4(6):762-769.

Temitope R 2010. Judicial Recognition and Enforcement of the Right to Environment: Differing Perspectives from Nigeria and India. NUJS Law Review, 3:423-434.

Terry M 2003. Employee representation: shop stewards and the new legal framework. Industrial Relations: Theory and Practice. Oxford, UK:Blackwell Publishers Ltd.

Thorsen DE 2006. What is neoliberalism. From http://folk.uio.no/daget/what\%20is\%20neo-liberalism\%20final.pdf. (Retrieved on October 10, 2013).

Umeokafor N, Isaac D, Jones K, Umeadi B 2014. Enforcement of occupational safety and health regulations in Nigeria: an exploration. From http://www.eujournal.org/index.php/esj/article/view/2921/2748. (Retrieved on July 2, 2014).

Vallas SP 2003. Why Teamwork Fails: Obstacles to Workplace Change in Four Manufacturing Plants. American Sociological Review, 68(2): 223-250.

Weiler PC 2009. Governing the workplace: The future of labor and employment law. From $h l=e n \& l r=\& i d=0 z 4$ owbwkoxac\&oi=fnd\&pg=pa1\&dq=weiler+pc+2009.+governing+the+workplace:+the+future+of+labor+and+employment+law\&ots= enqi9zosgj\&sig=jikpihlmkvomepqf0xcvcy6ivdq\#. (Retrieved on April 1, 2013).

Whitener EM, Brod SE, Korsgaard MA, Werner JM 1998. Managers as Initiators of Trust: An Exchange Relationship Framework for Understanding Managerial Trustworthy Behavior. Academy of Management Review, 23(3):513-530. 